\title{
TAKING THE INSTRUCTION OF LAW OUTSIDE THE LECTURE HALL: HOW THE FliPPED ClASSROOM CAN MAKE LEARNING MORE Productive ANd EnJoyable (For Professors AND Students)
}

\author{
PETER SANKOFF*
}

This article addresses the viability and utility of the "flipped classroom" concept in law school classrooms. The author argues that video capsules, as a means to lecture outside of the classroom, are an effective way to teach the so-called Generation $Y$ and reclaim the classroom. By using class time to concentrate almost entirely on problem-solving, students are more focused and engaged in the material. Although technologies create certain challenges for the future of legal education, the potential to reinvent the way course material is delivered will help law faculties reach a generation of students that are proving difficult to inspire using traditional means.

\begin{abstract}
Cet article aborde la viabilité et l'utilité du concept de «salle de classe renversée» à l'école de droit. L'auteur fait valoir que les capsules vidéo, remplaçant les cours magistraux en dehors de la salle de classe, constituent un moyen efficace d'enseigner à la soidisant Génération $Y$ et ainsi de récupérer la salle de classe. En utilisant les cours pour se concentrer presque uniquement sur la résolution de problèmes, les étudiants sont plus ciblés et mobilisés dans la matière. Bien que les technologies présentent des défis pour l'avenir de la formation juridique, les possibilités de réinventer la prestation de la matière aideront les facultés de droit à rejoindre une génération d'étudiants qui s'avèrent difficiles à inspirer par les moyens traditionnels.
\end{abstract}

\section{TABLE OF CONTENTS}

I. INTRODUCTION . . . . . . . . . . . . . . . . . . . . . . . . . . . . . . . . . . . 8982

II. Why Use CAPSUles? . . . . . . . . . . . . . . . . . . . . . . 894

A. A Changing Student Body . . . . . . . . . . . . . . 894

B. A Desire to Integrate More Problem-Solving INTO MY CLASSES . . . . . . . . . . . . . . . . . . . . 896

C. The Continued NEED TO TRANSMit

III. CAPSUlES: WHAT ARE THEY? . . . . . . . . . . . . . . . . . . 898

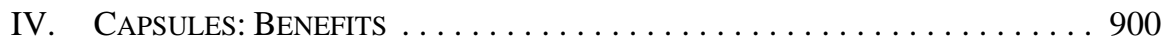

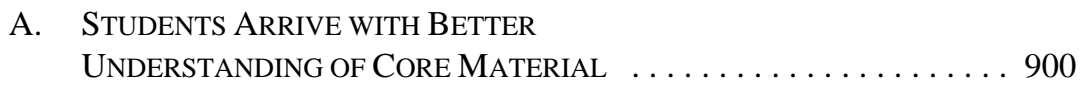

B. SAves ClassRoOM Time $\ldots \ldots \ldots \ldots \ldots \ldots \ldots \ldots \ldots \ldots \ldots$

C. Engages With Visual LEARNERS $\ldots \ldots \ldots \ldots \ldots \ldots 1$

D. PRovides A FleXIBle LEARNING EXPERIENCE . . . . . . . . . . . . . 902

E. MAKES OPTIMAL USE OF PROFESSIONAL

KNOWLEDGE AND EXPERIENCE . . . . . . . . . . . . . . 902

V. CAPSUles: ReAl AND PuRPORTEd ConCERnS $\ldots \ldots \ldots \ldots \ldots \ldots . \ldots 903$

A. RESOURCE INTENSIVE $\ldots \ldots \ldots \ldots \ldots \ldots \ldots \ldots \ldots \ldots \ldots$

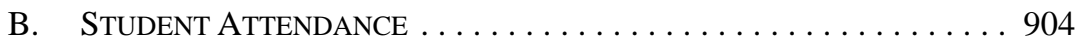

Professor, Faculty of Law, University of Alberta. The author wishes to thank the University of Alberta's Teaching and Learning Enhancement Fund, which provided research funding that was of great assistance with both this article and the capsule project as a whole. I am also grateful for the help provided in preparing this article by two Faculty of Law students: Megan Kheong (research) and Lamont Bartlett (administering and compiling surveys). In addition, I would like to thank participants at the workshops in which I presented on this technique for their valuable comments and suggestions. Special thanks to Mohsen al-Attar for his comments on an earlier draft of this work. 
C. TeChnical Issues for StUdents $\ldots \ldots \ldots \ldots \ldots \ldots \ldots$

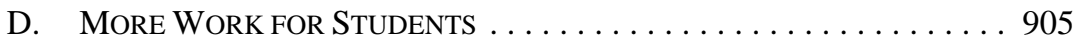

VI. The FUtURE OF CAPSUlES IN LAW SCHOOL . . . . . . . . . . . . . . . . 906

\section{INTRODUCTION}

Since this conference has set as its goal — as well as its title - the generation of discourse about the future of law school, it seems appropriate to begin with at least a few words providing my thoughts about such a future. I do not fancy myself much of a soothsayer, as most of my forays into predicting what might come to pass have ended in failure or, at best, in limited success. ${ }^{1}$ Nonetheless, in considering the law school of the future and forecasting what it might look like, I feel confident in offering one modest prediction: sooner rather than later there will be far fewer of the "talking head" lectures that continue to dominate most larger classes taught in law faculties today. To the extent this teaching method ever truly worked, it no longer represents an effective mode of engaging with and shaping the law students who populate our classrooms. Moreover, by its very nature, it involves a tremendous amount of redundant effort from professors, and constitutes an inferior mode of transmitting important information to a large group of learners.

Though a perusal of the academic literature recounting new developments in legal education might lead one to believe that lecture-based teaching is either extinct or rapidly declining, my own experience suggests it remains fairly widespread. In the past five years, I have taught as a full-time faculty member or visiting professor at six different institutions. ${ }^{2}$ By talking with students and colleagues, and sitting in or watching parts of classes in a range of subjects, I have observed that the lecture format remains a dominant force, ${ }^{3}$ especially in classes comprised of 40 students or more. ${ }^{4}$ To be sure, variants on the framework exist. Some professors take questions intermittently from students. Many offer portions of their classes in a Socratic framework, with a handful of students dominating the discussion. ${ }^{5}$ Some use Microsoft PowerPoint or other types of animation to supplement the experience. Notwithstanding these distinctions, large law classes still tend to be lecture intensive, with a professor speaking from the podium at the front of the room and students frantically typing notes in response.

University of Auckland; University of Western Ontario; University of Alberta; University of Melbourne; Lewis and Clark College of Law; Niigata University, Japan. 3 My impression is by no means unique. See e.g. Benjamin V Madison III, “The Elephant in Law School 85:3 U Det Mercy L Rev 293 at 301; Joanne Ingram \& Robin A Boyle, "Generation X in Law School: How These Law Students Are Different From Those Who Teach Them” (2006) 56:2 J Legal Educ 281 (predominant teaching method in law is Socratic method combined with straight lecture at 285).

$4 \quad$ Though I believe the education tool I am discussing here can be effective regardless of the size of the law school class, I recognize that the problem with teaching methods that I discuss in this article are most acute in larger classes of 40 students or more. See generally Madison, ibid at 299-300.

When used as a primary teaching mechanism, there is little difference between these forms, as Socratic questioning, "though appearing to be interactive, is really a passive experience for all but the student being quizzed" (Louise Bond-Fraser et al, "The Changing Face of Law Schools: The Impact of Generation Y,” online: (2011) 14 Perspectives 3 at $3<$ http://www.aabss.net/jbss/archives-of-the-aabssjournal-and-aabss-perspectives $>$ ). 
I have three major objections with the lecture as a primary mode of instruction. First, although both lecturing and the Socratic method may at one time have been an effective way of sharing knowledge or imparting it to students, the majority of today's students do not learn from these methods effectively, often struggling to absorb the professor's carefully crafted teachings. A related problem is that of student disengagement. In today's modern classroom, students have a multitude of techniques available for self-distraction at their fingertips, and make use of them frequently. ${ }^{6}$ Finally, in a different vein, I believe the lecture often amounts to a wasteful expenditure of precious resources. It fails to make optimal use of a professor's experience, knowledge, and abilities, instead consigning him or her to a lifetime of performance repetition, transmitting the same information — often inefficiently — to a different group of students year after year.

With a new generation of law students entering our classrooms, it seems inevitable that the future will involve less of this technique. The driving forces of change are likely to be a combination of student demand and the availability of technology that allows us to realize the objective of the lecture more effectively, permitting class time to be reconceptualized in a manner that increases the likelihood it will be productive for both student and teacher alike.

This article is meant to contribute to the emerging discourse about the ways in which law professors can move away from lecture-based teaching and towards more enriching forms of education. It does so by chronicling the use of video "capsules" in my course on the law of evidence in 2012, a move that followed an earlier decision to transform the class from the lecture format described above - albeit one that involved short bursts of problem-solving — to a course that attempts to get students to learn almost exclusively by doing. To help students come to grips with some of the more difficult nuances of the law, part of what a lecture would normally encompass, and put them in the best position to succeed in problemsolving, I created a number of short computer generated lectures called "capsules," which were available to students on a course web page. These 10 to 20 minute instructional videos were designed to give students a sound understanding of the basic principles that would be utilized in class on the day in question and simultaneously provide them with a review mechanism they could refer to throughout the duration of the course.

Though still relatively rare in the law school classroom, ${ }^{7}$ neither this form of teaching nor this use of educational technology is new. For example, the Khan Academy has created a huge online learning centre for students of all ages, using short lectures and video diagrams

6 The "Facebook" phenomenon has been heavily commented on in the academic literature, and is a consistent topic of discussion at every law faculty I have ever been a part of. See Eric A DeGroff, “Training Tomorrow’s Lawyers: What Empirical Research Can Tell Us About the Effect of Law School Pedagogy on Law Student Learning Styles” (2012) 36:2 S Ill ULJ 251; Anne Matthew, "Managing Distraction and Attention in Diverse Cohorts: 21st Century Challenges to Law Student Engagement" (2012) 12:1 Queensland University of Technology Law and Justice Journal 45. The response of some law professors has been to banish laptops from the classroom. See e.g. Nancy G Maxwell, "From Facebook to Folsom Prison Blues: How Banning Laptops in the Classroom Made Me a Better Law School Teacher,” online: (2007) 14:2 Rich JL \& Tech 4 <http://jolt.richmond.edu>.

There are certainly professors who use aspects of this formula, usually by providing podcasts or other audio recordings of lectures as a supplemental tool for students to enhance understanding of core concepts. A few law journal articles have discussed using similar ideas in the classroom. See e.g. Jennifer Ireland, “Blended Learning in Intellectual Property: The Best of Both Worlds” (2008) 18: 1 \& 2 Legal Education Review 139 (audio podcasts provided to students before seminars). See also Craig Forcese, Bleaching Law, online: Bleaching Law <http://craigforcese.squarespace.com/bleaching-law/>. 
to teach a range of subjects effectively. ${ }^{8}$ University professors in a range of disciplines have also seized on the "flipped classroom" concept as a means of delivering course content. ${ }^{9}$ This technique provides students with prepackaged video or audio material to help enhance student performance in complex problem applications during class time.

In this article, I will assess the viability and utility of this approach in law school classrooms. First, I will explain the rationales that lead me to include video capsules in my evidence course. Next, I will set out how I create capsules, and how they are utilized within the context of my class. Finally, I will conclude by examining the primary benefits and drawbacks of the technique.

\section{Why Use CAPSUles?}

\section{A. A Changing Student Body}

Though it seems trite to say, students entering law school today do not learn or behave like their historical counterparts. Generational change of this sort has been happening for as long as law has been taught in universities, but many believe this latest iteration is the most dramatic that law schools have ever seen. ${ }^{10}$ The reasons for the change are multifaceted, but the most significant seems to be the manner in which today's students - currently belonging mostly to the so-called Generation $\mathrm{Y}^{11}$ — were born and raised on technology, and the way these students regard devices like the laptop, tablet, and mobile phone as the preferred platforms for learning, communication, and entertainment.

If prompted, most law professors would admit to being aware that this new group of students is creating challenges, even if they are not entirely sure what to do about it. Over time, trusted methods of instruction started to feel stale and ineffective, and classrooms have become quieter as a consequence, filled mostly with the sounds of the professor's own voice. Participation from a wide group that could once be assumed or mandated has become reluctant and many students react to attempts designed to compel them to speak by hiding in the back of the room or even skipping class altogether. Moreover, what used to be a sea of engaged student faces has been replaced by half-hidden visages crouching down behind a laptop or tablet. In assessing the transformation that is already well underway, Diana Donohoe has perceptively described what many law professors feel in their classrooms today:

Visit The Khan Academy, online: Khan Academy <http://www.khanacademy.org>.

See e.g. Jeremy F Strayer, "How learning in an inverted classroom influences cooperation, innovation and task orientation” (2012) 15:2 Learning Environments Research 171; Maureen J Lage, Glenn J Platt \& Michael Treglia, "Inverting the Classroom: A Gateway to Creating an Inclusive Learning Environment" (2000) 31:1 Journal of Economic Education 30; Julie Foertsch et al, "Reversing the Lecture/Homework Paradigm Using eTEACH ${ }^{\circledR}$ Web-based Streaming Video Software” (2002) 91:3 Journal of Engineering Education 267.

10 Catherine Dunham \& Steven I Friedland, "Portable Learning for the 21st Century Law School: Designing a New Pedagogy for the Modern Global Context” (2009) 26:3 J Marshall J Computer \& Info L 371 at 380, suggest that "[t]he generational gap resulting from changes in technology and expanded access to information constitutes what may possibly be the most significant gap between faculty and students in the entire tradition of the modern ... law school.” 
What are your students doing on the other side of their laptops as they peer over their screens during class? Perhaps you are frustrated because you know what they are doing; they are checking e-mail, Twittering, and IM-ing their friends. If you feel as if you are losing your students' attention to the lure of the laptop, you are not alone. Many law professors feel as if they are fighting a battle against the students' laptops in the classroom. Some professors have turned off the wireless routers in their classrooms while others forbid the use of computers altogether. Most professors continue to lecture using the Socratic Method though many students no longer are paying attention. As a result, both students and professors are often frustrated with their classroom experiences. Professors label their frustration as a war against the laptops, whereas students consider it a battle against boredom. ${ }^{12}$

This frustration is no random occurrence. Studies examining the qualities of today's students tend to show that this group possesses a number of common characteristics that makes both lecturing and extended use of the Socratic method problematic. Most notably, Generation Y students are identified as being:

- $\quad$ Intent on using technology as part of the learning process;

- Visual learners;

- Multi-taskers;

- $\quad$ Learners with shorter attention spans; and

- $\quad$ Of the belief that learning should be both interactive and collaborative in nature. ${ }^{13}$

In addition, these students are not naturally inclined to participate, both because they do not see the value of doing so and also because they are hesitant to take criticism publicly: these are features that render both the lecture format and full-scale Socratic method ineffective, unless methods to compel participation are imposed. While many professors encourage students to pose questions and respond to those posed, the reality is that in most classes participation remains sporadic and confined to a small group of particularly eager individuals.

The result is an educational experience that fails to excite either professor or student. No matter how gifted an orator the professor might be, he or she is facing a student body that is either unwilling or unable to engage with what is being said, even though every incentive exists for doing just that. As Louise Bond-Fraser et al. have suggested, "the values, beliefs and learning-styles that [law students and professors have] as a result of their formative environment, make[s class time] more like a misfiring generation-synapse; the transmitter wants to transmit and the receptor wants to receive, but the signal is failing to cross the divide."14

12 Diana R Donahoe, “An Autobiography of a Digital Idea: From Waging War against Laptops to Engaging Students with Laptops” (2010) 59:4 J Legal Educ 485 at 485-86 [footnotes omitted, emphasis in original]. See also Matthew, supra note 6 at 50, reporting on a detailed Kansas State study, which concludes that "the [Internet generation] will simply tune out if the class is not engaging or is too slow." Madison, supra note 3; Bond-Fraser et al, supra note 5; Eric A DeGroff \& Kathleen A McKee, "Learning Like Lawyers: Addressing The Differences In Law Student Learning Styles” (2006) BYU Edu \& LJ 499; Ingram \& Boyle, supra note 3; Kristin B Gerdy, Jane H Wise \& Alison Craig, "Expanding Our Classroom Walls: Enhancing Teaching and Learning Through Technology" (2005) 11:1 The Journal of the Legal Writing Institute 263.

$14 \quad$ Bond-Fraser et al, ibid at 5. See also Degroff \& McKee, ibid at 505: "prior learning experiences of today's law students and, in some cases, their excessive childhood and adolescent exposure to visual stimulation, affect both the way they receive and absorb information and the way they process that information cognitively." 
The need to change the way we educate law students seems more obvious with each passing year. Failing to do so ignores the needs of our students and diminishes the educational experience. Using extremely strong language, Benjamin Madison urges professors to focus much needed energy on crafting new methods of instruction, and recognize that the "old ways" are dooming an entire generation of law students to a mediocre quality education:

\begin{abstract}
[L]aw schools ought to come out of denial — i.e., honestly recognize that when case-based, Socratic teaching dominates as much as it does, law students as a whole suffer. The method favored for over a century may allow some percentage of law students to excel. However, many, if not a majority, of law students fail to receive the quality of education of which the legal academy is capable of providing, if it only takes its head out of the sand. ${ }^{15}$
\end{abstract}

On a personal level, my desire to change emerged from a growing feeling of dissatisfaction with the teaching experience and a pervading sense that I was failing in my core mission as an educator. For years, I have noticed the declining interest of students in contributing questions and answers during class time, and although reviews of my course continued to be mostly positive, I felt students were no longer excited about the learning process or able to demonstrate a strong understanding of core evidentiary concepts. I knew instinctively that interest in the class rose and fell sporadically and that students were "checking out" from time to time into the wireless universe. The question was what to do about it.

\title{
B. A Desire to Integrate More Problem-Solving INTO MY CLASSES
}

In 2011, I made the decision to transform my evidence course from one that focused on case analysis, using lectures and some class discussion, to one that concentrated almost entirely on problem-solving. The objective was to build on the strengths of my students, based on the fact that they seemed to perform better and discuss the material more incisively when they were actively engaging with hypothetical examples. ${ }^{16}$ Problem-solving applies the philosophy of "active learning," a pedagogical approach recommending that "during classroom time, students ... be engaged in behavior and activities other than listening." 17 Active learning also asks students to "undertake higher-order thinking, forcing them to engage in analysis, synthesis, and evaluation." 18

In order to achieve this change, I completely redesigned the course curriculum and format. Rather than having students read cases and assess them, I provided students with a textbook that explained basic aspects of evidence law and attempted to teach them the more complicated issues and illustrate difficulties in application by having them work on evidentiary examples in class. The course was loaded with problems of all sorts, some of

See e.g. Joan Catherine Bohl, "Generations X and Y in Law School: Practical Strategies for Teaching the ‘MTV/Google’ Generation” (2008) 54:4 Loy L Rev 775 at 784-85.

Paul L Caron \& Rafael Gely, "Taking Back the Law School Classroom: Using Technology to Foster Active Student Learning” (2004) 54:4 J Leg Educ 551 at 552.

Ibid. 
which were founded on actual cases, and others that came from television or film scenarios that we would watch and then attempt to resolve. A sizeable amount of small group work was integrated into every class. Students were often asked to advocate for one party or another, and problems were dissected in detail. The goals were to: (1) increase the students' ability to apply legal doctrine; (2) extract key principles, including how particular rules related to broader themes in evidence law; (3) assess difficulties in applying the law; (4) get a sense of the surrounding social context; and, (5) critique the law and assess how it might develop in the future.

To my eyes, the change was immensely successful. Students were enthusiastic about the "real world" aspect of the class and more inclined to participate as a result, especially once they had time to discuss problems in small groups. Furthermore, they seemed to grasp the nuances of the law more accurately once they had engaged with actual problems, rather than simply reading judicial solutions. Finally, my concerns regarding student disengagement abated entirely, as the nature of the class rarely permitted any extended time for staring at a computer. One student even complained on an evaluation, perhaps jokingly, that he or she "was disappointed not to have time for Facebook."

To be clear, my objective here is not specifically to advocate for problem-solving as a solution to the difficulties in teaching posed by new student learning styles. ${ }^{19}$ Rather, I wish to explore how the decision to change my method of instruction by reducing lecture time and increasing the focus on problem application successfully eliminated certain concerns from my classroom, but in the process, it unexpectedly created a new one.

\section{The Continued NeEd to TRANSMit AND EXPLAIN INFORMATION}

Without question, moving away from lectures to group discussion improved the classroom dynamic and made students more interested in what was going on during class time. Participation went up and, in my opinion, student understanding of the law of evidence improved as well. ${ }^{20}$ Nonetheless, the students were less ecstatic with the process than I was, and many remarked upon it in their course evaluations. Though they liked the interactive component of the exercise, several students felt unequipped to contribute properly to the problem-solving process, and the reason was because they did not feel they possessed a strong grasp of basic concepts before jumping into a discussion of the problems.

At first this struck me as an unusual complaint, for I had crafted the problems with the aim of using them as a device to extract important lessons about the rules of evidence, the principles upon which these rules were based, and nuances in the application of the law. Before each lecture, students were provided with basic readings about the rules to be

19 For particular discussion on the value of problem-solving as an educational tool, see Gregory L Ogden, “The Problem Method in Legal Education” (1984) 34:4 J Leg Educ 654; Myron Moskovitz “From Case Method to Problem Method: The Evolution of a Teacher” (2004) 48:4 Saint Louis U LJ 1205; Lisa A Kloppenberg, “'Lawyer as Problem Solver:' Curricular Innovation at Dayton” (2007) 38:2 U Tol L Rev 547.

20 I recognize it is anecdotal, but I felt that the exam answers from the two years in which I have focused on problem-solving have been, by far, the best I have read in my career. 
discussed that day, and that seemed a sufficient way of providing a framework that would put students in a position to grasp the lessons from each problem successfully.

In hindsight, I realize my approach was flawed, as the students' concern was directed almost exclusively towards their ability to process the material effectively before coming to class. It struck me that in setting up the new framework, I had neglected to consider fully the role that lecturing can still play: providing students with a better understanding of concepts that are sometimes difficult to extract from written material alone. ${ }^{21}$ Although it may not be the most interesting part of the learning process, a large proportion of students still value the lecture as a way of helping to evaluate or decipher particular constructs that can be difficult to understand when reading primary materials alone..$^{22}$ As Joan Bohl puts it: "[I]t is no longer really a question of the information itself.... Information is just a click or a commercial outline away. But ... the ... professor is more than the sum of available knowledge. He or she can breathe life into the information and so synthesize it into a meaningful whole."23

My failure to "breathe life" and "synthesize" the law of evidence meant that the problemsolving exercises ended up being less useful than I desired. Students would come to class with a vague idea of what was going to be discussed and then be thrust into a problem scenario. But without a clear understanding of the "basics," performing at the more advanced level I was hoping for became a challenging and somewhat frustrating experience. Even when things ultimately got clarified during group discussion and recap of the problems, many students - according to their evaluations - started "turning off" during the exercise portion of the class, feeling they were not gaining enough from the process or enjoying it, simply because they did not feel adequately prepared to succeed.

This created somewhat of a quandary. Problem-solving can be very effective, but doing it in a way that gives students room to discuss the questions in small groups, share findings with the class, and receive feedback, is incredibly time-consuming. Moreover, devoting time at the beginning of each class to an introductory lecture seemed contrary to the whole rationale of switching modes of instruction. I was concerned that it would become difficult to get the "best of both worlds" unless I altered the traditional classroom paradigm and somehow prepared my students outside of class for the types of activities that I felt were most beneficial inside the class.

\section{CAPSUles: What ARE THEY?}

The proposed solution to my new problem was something I named "evidence law capsules." In its most basic form, an evidence law capsule is a short video that combines a condensed audio-recorded lecture with a computer "whiteboard." Created through use of a computer tablet and electronic pen, the capsule contains a series of pictures, drawings, and notations supplemented with a voice-over. Running 10 to 20 minutes in length, the capsule

21 To be clear, this is not meant to suggest that lecturing "works" as a form of instruction. Rather, I am suggesting that a certain amount of lecturing can be useful to explain concepts that students are having trouble grasping.

22 Ireland, supra note 7 at 142, comments that lectures "can reinforce concepts already learned through the students' own reading, explain areas that are unclear and provide a point of comparison for students to check their own understanding of the material against the explanations provided in the lecture.” Bohl, supra note 16 at 793 [footnotes omitted]. 
addresses rudimentary elements of evidence law. The goal in creating capsules is not to replicate a lecture or address every possible aspect of a topic, but rather to provide students with a basic underpinning of whatever issue is to be addressed in class on the day in question.

Although I did not create capsules with this initiative in mind, I learned afterwards that I was in effect utilizing an emerging teaching methodology commonly referred to as either the "flipped” or "inverted” classroom, or "blended learning." The term "flipped classroom" refers to the idea that the traditional classroom is being flipped on its head with the lecture portion of the class conducted online, in a way that allows students to spend classroom time interacting with each other and the professor. ${ }^{24}$ Usually, although not exclusively, ${ }^{25}$ the use of the flipped classroom enables the professor to engage in non-traditional teaching methods, mainly because it is no longer necessary to spend as much time and energy transmitting core knowledge to students.

In my class, capsules performed the role of a short lecture designed to introduce students to certain legal concepts and then illustrate how particular rules fit into the larger context of evidence law. For example, in my capsule on the hearsay rule, I begin by showing illustrations of how the problem addressed by the rule actually arises in court - when a witness relates an out-of-court statement, or when documents or other matters are introduced as exhibits - and then diagram more complex versions, such as implied assertions. Next I set out the fundamentals of how the law reacts to these scenarios. Sometimes I provide historical context, or point to controversies connected to the law, and I normally try to situate the rule within a broader framework of evidentiary principles. Again, for hearsay, this means showing how the rule is tied to the preference for oral testimony and cross-examination. The information is not designed to spoon-feed students complex aspects of the law of evidence, or parse through potentially troublesome applications. Instead, it is designed to provide enough background so that more complicated queries can be addressed effectively in class.

The capsules were created using an iPad tablet and a software application called Doodlecast ${ }^{26}$ that allows audio recording to be conducted while the user adds graphics to a blank canvas or preloaded visual images. Advances in technology have eliminated two of the most typical objections to this sort of endeavour: cost and complexity. While recording lectures or podcasts was at one time a difficult task requiring expensive technology, beautifully crafted and individualized videos can now be made for the cost of a tablet - a one-time expense of around $\$ 600$ — and the price of a good cup of coffee (or less) for an application that allows the user to construct the videos in an accessible way. As many

24 As Strayer, supra note 9 at 172, suggests, "the inverted classroom course design was developed out of the desire [to] move the lecture outside the classroom (if not replace it with technology) to make room for in-class investigations.” Blended learning similarly refers to models that involve elements of online learning blended with standard classroom teaching (Ireland, supra note 7 at 139-41).

25 Graham Brent Johnson, Student Perceptions of the Flipped Classroom (MA Thesis, University of British Columbia, 2013) [unpublished], online: UBC cIRcle <http://circle.ubc.ca/handle/2429/44070>. Johnson notes at 76 that "[t]he Flipped Classroom ... should be viewed as mindset rather than a pedagogy. The traditional Flipped Classroom definition requires students to watch their lessons at home and work on various activities in the classroom, but that doesn't mean every Flipped Classroom needs to operate in this fashion."

26 Doodlecast can be examined online: Doodlecast Pro <http://doodlecastpro.com>. There are other applications that provide a similar function. 
professors have already discovered, use of these applications is both easy and intuitive, and it results in videos with a fairly professional look and sound.

\section{CAPSUles: BenEFits}

In 2012, I provided my evidence class with a capsule on basic principles before every class of the semester - 26 in total. This had numerous benefits, which are discussed below. Near the conclusion of my 2012 course, I received ethics approval from the University of Alberta to survey my students anonymously about the experience. Aspects of the survey are referred to below.

\section{A. STUDENTS ARRIVE WITH BETTER UNDERSTANDING OF CORE MATERIAL}

Perhaps the most important benefit of capsules is that they provide students with background knowledge before they enter the classroom, which allows for a more productive use of classroom time. As Jennifer Ireland has noted, "[t]he acquisition of ... 'declarative ... knowledge' must take place before that knowledge can be applied to problems and provide the basis for the type of 'intellectual inquiry' seminars are intended to encourage.”27

Just about every study that has been conducted on the flipped classroom touts the benefit of having students who are more prepared when it counts. Students who watch or listen to recorded material before class feel more competent in their understanding of the relevant topic, which has the consequential benefit of reducing shyness and inhibition in the classroom..$^{28}$ As one study suggested, "by listening to background material and being exposed to the terminology used in the subject, students are likely to be better prepared to participate in classes, and to do so with motivation and confidence." ${ }^{29}$

The survey of my 2012 evidence class reinforces this point. Despite expressing a few mixed views about problem-solving as a whole, students were unanimous in their opinion that capsules were a useful way of assisting them in understanding material before class. Seventy-one percent of respondents agreed that watching capsules before class helped a great deal in preparing for class. The remaining 29 percent agreed that watching capsules helped "somewhat." Not a single student responded that capsules were ineffective in preparing them for class. ${ }^{30}$

Ireland, supra note 7 at 143 [footnotes omitted]. and concluded that the tool has a sound track record of "positively influencing student learning outcomes and student performance.” See also Strayer, supra note 9 (students in flipped class are "more willing to participate" at 188).

29 Mark JW Lee, Anthony Chan \& Catherine McLoughlin, "Educational Podcasting Using the Charles Sturt University Flexible Publishing Platform" in T Reeves \& S Yamashita, eds, Proceedings of World Conference on E-Learning in Corporate, Government, Healthcare, and Higher Education (Chesapeake, Va: Association for the Advancement of Computing in Education, 2006) 2894 at 2894. See also Donahoe, supra note 12 at 504: "By piquing their interest out of class with interesting and interactive material, students come to class ready to learn and ready to teach others. They ask more pointed questions, pressure me to dive deeper into the subject matter and force each other to think more critically about the material than they had when I used traditional texts."

30 I recognize this is a small sample size - 36 students in total. My objective is to continue surveying in coming years to obtain a more comprehensive review of student opinion. 


\section{B. Saves ClassRoom Time}

A common refrain of law professors is that class time is valuable, and that finding time to cover all the required material is an increasingly difficult task. Capsules provide an easy solution for time shortages and cluttered curricula. As Benjamin Madison suggests:

\footnotetext{
If a professor can save fifteen minutes in class, and avoid time-wasting confusion, she can then move to more in-depth questions and further push students in dialogue. The professor is in charge of time management in the classroom, and it is her responsibility to ensure that specific topics are covered before the end of the semester. If it is the calling of a professor to teach her students the best she can, then she should strive for both efficiency and productivity in the classroom. ${ }^{31}$
}

Capsules preserve class time for where it is needed most — whether for problem-solving or other means of engaging students. Shifting basic explanations of complex “black letter" law from the first 20 minutes of class to an online venue is an ideal way of making difficult choices about which content to include in any seminar.

\section{ENGAGES WITH VISUAL LEARNERS}

My choice to use video capsules, as opposed to audio recordings, stems from the belief that many students today flourish when explanations are provided with accompanying graphic displays. Numerous studies reveal that more and more of today's students identify themselves as visual learners, ${ }^{32}$ best able to process information when it is provided in a medium they can watch, with associated illustrations. Diana Donahoe and others champion the use of visual tools in law school, noting that "[m]ultimedia, such as computer graphics, video and animation, will help engage digital students by bringing material to life and helping them understand the context and relevance of the material to the 'real world., ’33

To be sure, using video and other types of multimedia in the classroom is nothing new. But capsules recognize the needs of today's students and take the process a step further, providing a video in which concepts can be explored in real time with a clear graphic interface. By combining audio description from the professor with visual imagery, capsules allow students with different learning styles to interact with the information in a multisensory fashion. ${ }^{34}$ instruction may [result in] an increased prevalence of visual learners in today's law school classes" [footnotes omitted]. 


\section{PROVIDES A FLEXIBLE LEARNING EXPERIENCE}

Another key advantage of capsules is that the instruction provided is available at all times and students can choose exactly when they wish to learn. ${ }^{35}$ The lesson can also be accessed on multiple occasions, allowing students to obtain reinforcement of the concepts learned in class $^{36}$ or assistance with matters they were unable to grasp completely from the problems. In other words, capsules operate prospectively and retroactively, providing students with lessons they can access before class, after class, and when reviewing for exams at the end of semester.

The availability of capsules also accords with the way students are used to getting information in today's society — through access on demand — which makes the learning process more consistent with students' experiences in other parts of life, and more enjoyable as a result. ${ }^{37}$ As Catherine Dunham and Steven Friedland have suggested, it is important for universities to break away from the notion that teaching is restricted to the classroom experience. ${ }^{38}$ Instead: "[t] eaching can and should occur even after the fixed-location class has ended.... [A] more portable learning environment would better match the changing world and make legal education more effective.”39

\section{E. MAKes Optimal USE OF Professorial KNOWLEDGE AND EXPERIENCE}

Although the use of supplemental learning techniques like capsules is extremely useful in a problem-solving course, the benefits provided are not restricted to this milieu. Even if the lecture remained a productive means of instructing the law students of today, it would still be worthwhile to include capsules in most courses. The reason is simple: capsules offer an attractive way of transmitting basic information to students, reinforcing ideas discussed in class, and accomplishes both in a manner that saves time for professors and students alike.

Let me illustrate through an example. I teach a first year class on criminal law and I have traditionally allocated one class at the end of the semester to introduce students to law school exams. Having marked these exams for years, I have assembled a list of "tips" designed to show students what they should and should not do on a law school exam and, like many professors, I find it is useful to pass this on before exams start.

It eventually occurred to me that this effort was wasteful in many ways. First, I lost an entire class to this process and it was a miserable class to provide, as students were already

I believe there is great power in getting to choose whether to learn, which helps explain the power of supplemental tools like capsules. Skeptics might contend that students "choose" to come to class as well, and do not pay attention, but in my view, it is a different kind of choice, one that is influenced by peer pressure and routine. A student who opens their computer and chooses to watch a capsule is making a more unencumbered type of decision.

36 See Madison, supra note 3 (importance of reinforcement to "get the information from long-term memory to working memory" at 310).

See Gerdy, Wise \& Craig, supra note 13 at 263-66.

Dunham \& Friedland, supra note 10.

Dunham \& Friedland, ibid at 373. For a detailed discussion of the various uses that can be made, as well as the advantages, of podcasts, see Kathleen Elliott Vinson, "What's On Your Playlist? The Power of Podcasts as a Pedagogical Tool” (2009) 2 University of Illinois Journal of Law, Technology \& Policy 405. 
stressed about the upcoming exam experience. Second, it led to countless questions from students who were unaware of what to expect as the lecture proceeded and who quite sensibly posed questions as they occurred to them. Finally, it was provided in a way that required students to scribble notes as I explained the pitfalls of bad exam strategies. Not surprisingly, many of these lessons were not absorbed.

Last year, I sidestepped the process entirely. I created a 40 minute "Exam Preparation Capsule" that delved in-depth into common student errors, tips to improve performance and specific details about the format of the exam I was going to set. Though it took two hours to create, the capsule is now available to my students at all times. Instead of a one hour lecture on exam preparation where students ask questions and struggle to process the answers, I hold a ten minute question and answer that focuses on issues raised in the capsule. I never have to prepare or speak on exam strategy again. If need be, I can update the capsule as new matters arise.

The benefits of proceeding in this manner should be obvious. First, class time is retained for teaching things that are more valuable. Second, my time is used more productively, as I can provide students with an extra hour of useful instruction on criminal law as opposed to the repetition of basics. Finally, my energy and enthusiasm are kept for the places in which I can provide the most utility to students - actually helping them to grow and learn.

\section{CAPSules: ReAl AND PuRPorted Concerns}

The move to a flipped classroom framework is not a utopian change that makes teaching difficulties suddenly disappear; further, the approach has been challenged on a number of different grounds. As discussed below, my feeling is that critics have overstated most of the purported deficiencies, though there is at least one major obstacle that cannot be so easily ignored.

\section{A. RESOURCE INTENSIVE}

To me, the most significant challenge in transitioning to a flipped classroom environment lies in the fact that capsules or similar initiatives are time-consuming to create and require a large investment from any professor who wishes to use them. The expenditure of effort lies in two places: planning and execution. Though one might guess that physically creating capsules is the difficult part, the true challenge lies in attempting to seamlessly integrate outof-class and in-class elements. ${ }^{40}$ This process requires considerable care in thinking about the timing needed for each subject, as capsules are not easy to manufacture or alter on the fly. Students can easily become confused if material is being provided in an inappropriate manner, especially where the capsules do not match what is being covered in class. ${ }^{41}$ important to structure the face-to-face and the online portions of the learning experience so that they coherently support one another to help students to achieve the learning goals for the course."

41 Pressures can also arise during the teaching process. Running late on one subject inevitably creates a "capsule backlog” that cannot be swiftly rectified. 
In addition, there is the time required to execute the capsules themselves. ${ }^{42}$ Again, this effort should not be underestimated. Each capsule ran between 10 to 20 minutes with crafting, producing, and editing the capsules being a commitment of at least an hour each although the time required did decrease as I became more comfortable with the technology. Still, a time commitment of 26 hours, plus the many hours involved in planning what each capsule will contain and how each capsule will mesh with class developments, is not insignificant.

It is worth noting that the expenditure of effort is not ongoing and that, with proper planning, an integrated classroom experience can be created in a manner that allows it to be used effectively in subsequent years. ${ }^{43}$ Additionally, with appropriate training, delivery of content can be done in a time-effective way that limits the professor's overall commitment. Nonetheless, any way you look at it, transferring a standard course to a flipped classroom with capsules requires significant time and effort, regardless of how worthwhile this transition might be.

\section{B. STUdent ATtendance}

A consistent concern with learning initiatives that exist outside the classroom is the worry that students will stop attending class altogether. At workshops where I presented my research on capsules, this was raised by a number of skeptical professors, and it is certainly something that should be monitored. Nonetheless, intuitive as it might seem, there is no evidence to suggest that providing supplemental learning tools online discourages attendance, and quite a bit of experience suggesting the contrary. ${ }^{44}$

Indeed, with well-designed flipped classroom initiatives, attendance rarely seems to be a problem. $^{45}$ The reason is twofold. First, classes in a flipped environment tend to be more interesting to students, which spurs attendance. More importantly, students quickly discover that the online material is simply not sophisticated enough to replace classroom attendance. In my evidence course syllabus, I emphasized that what we were going to do in class went considerably beyond anything that would be covered in the capsules, and included both policy discussion and complex fact application. Moreover, I explained that the exam was going to be very similar to the problems we confronted in class. In the class survey, only 3 percent of students agreed that the presence of capsules was a reason to miss class. The general sentiment of the feedback, encapsulated by one response, was that "the capsules are not as thorough [or] detailed and don't provide the same engagement with the material as I get from a class discussion." 46 To be sure, students appreciated the fact that capsules were there if a class had to be missed, ${ }^{47}$ but the capsules did not seem to create an incentive to miss

Ireland, supra note 7 at 157-58, remarks, "[t]echnical challenges ... [in learning how to create podcasts were] not as difficult as one might first expect ... [but] the time taken to pre-prepare podcasts was really quite extensive and is not to be underestimated." In 2013, I received funding to improve the graphic design and look of the capsules which necessitated a complete overhaul, but for 2104, my intention is to use these new capsules again, without modification. See e.g. Sarah Bryans Bongey, Gerald Cizadlo \& Lynn Kalnbach, "Explorations in course-casting: podcasts in higher education” (2006) 23:5 Campus-Wide Information Systems 350 at 357-59.

See Ireland, supra note 7 at 156-57; Matthew, supra note 6 at 46-48.

Survey response, on file with author.

Ninety-one percent of students referred to the capsules as being better than just getting another student's notes if they had to miss a class for some reason. 
class, and attendance throughout the year was comparable to other evidence seminars I have taught.

\section{TECHNICAL IsSUES FOR STUDENTS}

Some critics of the flipped classroom have suggested that use of online learning creates a number of inequities, most notably for students who might be unfamiliar with the technology, and for students who do not have access to the Internet at home. Studies on this issue, as well as my own experience, suggests this concern is also somewhat overblown. ${ }^{48}$ To begin with, the technology in question is incredibly simple to utilize, and any student with even basic familiarity with the Internet will be able to access and play video capsules easily. I did not receive a single complaint with respect to accessibility, and every student in my class reported being able to use capsules without difficulty. With each passing year, this concern recedes in importance, as it is hard to imagine many students entering law school today who are unable to use the Internet at all. ${ }^{49}$

Research into online learning in universities also suggests that access, in terms of equity, is not a serious concern either. Today, the overwhelming majority of students have access to the Internet at home and through mobile devices. Moreover, virtually every law school provides access to the Internet without cost through a dedicated computer room, or free wireless access. Students who wish to access the material on campus should be able to do so quite easily. ${ }^{50}$

\section{MORE WORK FOR STUDENTS}

Today's law students have a range of competing commitments. In addition to a full course schedule, many engage in a range of extracurricular activities including law clinics, and, in contrast to past generations, many work part-time to support the rising cost of their education. ${ }^{51}$ Without question, educators should be careful about imposing new obligations on students.

That said, it is difficult to see how capsules are somehow more onerous than other types of pre-class preparation, and in my course they were designed to reduce the need of students to delve through and attempt to decipher primary source materials. There is every reason to believe capsules minimize the time required for students to appreciate the legal concepts they will need to use in class. Careful focus on what materials are required each day and keeping capsules to a manageable length can help ensure that the time required for a flipped

A 2007-2008 survey, already somewhat dated, shows that 82 percent of students entering university own laptops and use them in classes: Romulus Cismaru \& Magdalena Cismaru, "Laptop Use During Class: A Review of Canadian Universities” (2011) 8:11 Journal of College Teaching \& Learning 21 at 22.

49 Supplementary assistance can certainly be provided if difficulties arise. A bigger concern arises with students who suffer from visual or hearing disabilities. The former strikes me as less significant, since capsules can be played as audio podcasts, and many students reported listening to them without watching the graphics, stating that they were also useful in this format. Subtitles can certainly be created for the hearing impaired, if the need arises.

$50 \quad$ Johnson, supra note 25 at 77.

51 See Allan C Hutchinson, The Law School Book: Succeeding at Law School, 3d ed (Toronto: Irwin Law, 2009) at 87-88. 
classroom seminar is no more than students would have to spend preparing for any other class.

\section{The Future of CAPSUles IN LAW SCHOOL}

Though new technologies create certain challenges for the future of legal education, they also offer the potential to reinvent the way we deliver course content in exciting new ways, and may help faculty in better reaching a generation of students that are proving difficult to inspire using traditional means.

Capsules offer an exciting way of altering the paradigm that still dominates many large law school classrooms. The technique can be used to provide additional information that a professor has no time to address in class; to recap complex subjects; and to help students prepare for exams. The benefits of providing visually dynamic instruction in a flexible format, while saving classroom time for other matters, seem compelling enough to warrant considering the technique for almost any course.

That said, despite the time required to plan and execute a course transformation of this type, the primary advantage still lies in using capsules as part of a flipped classroom. Cutting out or reducing the standard lecture method of instruction offers professors the hope of teaching in a manner that better meets the diverse educational needs of today's students and lets law school become a more productive and enjoyable experience for all concerned. Hopefully the "future of law school" includes greater reliance upon technology that allow today's students to have a more enriching and engaged experience, helping law faculties to turn out graduates who are more skilled and better placed to deal with tomorrow's challenges. 